\title{
Seasonality of stable carbon and nitrogen isotopes within the pelagic food web of Taihu Lake
}

\author{
Q.F. Zeng ${ }^{1,2}$, F.X. Kong ${ }^{1 *}$, E.L. Zhang ${ }^{1}$, X. Tan ${ }^{1,2}$, X.D.Wu ${ }^{1,2}$ \\ ${ }^{1}$ State Key laboratory of Lake Science and Environment, Nanjing Institute of Geography and Limnology, the Chinese Academy of Sciences, 73 \\ East Beijing Road, Nanjing 210008, China \\ ${ }^{2}$ Graduate School of the Chinese Academy of Sciences, Beijing 100039, China
}

\begin{abstract}
Particulate organic matter (POM), dissolved organic matter (DOM), bacteria and cladoceran were sampled seasonally at Zhihugang Estuary and Lake Center in Taihu Lake. The $\delta^{13} \mathrm{C}$ of the four organic matter fractions showed consistent temporal variation, with heaviest values in summer and lower at other times of the year. The cladoceran $\delta^{13} \mathrm{C}$ showed a significant correlation with that of POM, reflecting a heavy dietary dependence on POM during the study period. The bacteria became enriched in ${ }^{13} \mathrm{C}$ compared with that of DOM throughout the sampling dates, although no significant relationship was found between the two fractions. $\delta^{13} \mathrm{C}$ values of POM, cladoceran and bacteria were all negative significantly correlated with oxidation and reduction potential (ORP), and specific conductivity (SpCond). As for $\delta^{15} \mathrm{~N}$, the seasonal pattern of food web components was variable. The POM $\delta^{15} \mathrm{~N}$ signature exhibited the most enriched isotope ratios during the summer months when dissolved inorganic nitrogen (DIN) nutrients were at their lowest concentrations. The consumption of DIN in summer can explain in part the progressive accumulation of heavy nitrogen isotopes during this period. Spatially, $\delta^{13} \mathrm{C}$ and $\delta^{15} \mathrm{~N}$ of the food web components were all slightly depleted at Estuary than that at Lake Center during the study period, possibly due to large allochthonous inputs at Zhihugang Estuary. Relatively wide ranges of stable isotopic values from both sites suggest that seasonality should be considered when attempting to establish food web structures in a eutrophic lake.
\end{abstract}

Keywords: pelagic food web, seasonal cycle, spatial variation, stable isotope, Taihu Lake,

\section{Introduction}

Stable isotope analyses are being used increasingly in studies of lake ecosystems. Potentially they can cast new light on food web structure and on sources of materials and their fluxes through ecosystems (Grey et al. 2001, Bastviken et al. 2003). Many studies rely on rather limited temporal sampling, with an inherent assumption that seasonal variation in the isotope values of the sampled organisms is small relative to the variation between food web components. However, the seasonal succession in the plankton community and changes in the spatial distribution of aquatic organisms make the temperate plankton food webs more complicated in time and space (Grey et al. 2004). So the information obtained from short-term studies may result in inaccurate assessment of food web structure based on phytoplankton. Therefore, examination on temporal and spatial variations of stable carbon and nitrogen in particulate organic matter (POM), dis-

\footnotetext{
* Corresponding author: E-mail: fxkong@niglas.ac.cn
}

solved organic matter (DOM), bacteria and cladoceran will be important for the understanding of pelagic food web structure constructed by stable isotopes.

Taihu Lake, the third largest freshwater lake (water surface area: $2,334 \mathrm{~km}^{2}$ ) in China, has received large amounts of untreated effluents and soil runoff by rivers from the watershed, suffering from eutrophication since 1990s (Hu et al. 2006). Cyanobacterial blooms have occurred from May to October in recent years (Kong \& Gao 2005). The seasonal variation in production is very pronounced, and causes substantial fluctuations in the isotopic composition of plankton organisms. The aims were to investigate the trophic pathways in a eutrophic lake, with particular emphasis on the temporal variations of stable carbon and nitrogen isotopes and the possible mechanisms underlying these variations.

\section{Methods and Materials}

This study was carried out in Taihu Lake a large, shallow eutrophic lake in China from April 2006 to January 
2007. Samples for stable isotope analysis were collected at Zhihugang Estuary $\left(31^{\circ} 30^{\prime} \mathrm{N}, 120^{\circ} 07^{\prime} \mathrm{E}\right)$ and Lake Center $\left(31^{\circ} 20^{\prime} \mathrm{N}, 120^{\circ} 10^{\prime} \mathrm{E}\right)$. Samples for POM were obtained by filtering water through precombusted Whatman GF/F filters (450C 4h) that had been rinsed with dilute $\mathrm{HCl}(0.5 \%)$ prior to use. The filters were immediately frozen at $-20^{\circ} \mathrm{C}$. Samples for DOM analysis were taken from the filtrate of the Whatman GF/F filters, dried at $60^{\circ} \mathrm{C}$. The dried residue was stored in a desiccator for later stable isotope analysis. Zooplankton was collected by a $64 \mu \mathrm{m}$ mesh net tows. Only live cladoceran (mainly Daphnia, Ceriodaphnia and Bosmina involved) were sorted by hand under a dissecting microscope to a dry weight of at least $2 \mathrm{mg}$. To separate bacteria for isotope analysis, bacteria were cultured according to a modified version of the method described by Coffin et al.(1989). In brief, $120 \mathrm{~mL}$ Whatman GF/D-filtered and $1,080 \mathrm{~mL} 0.2$ $\mu \mathrm{m}$-filtered lake water was incubated in triplicate glass bottles in darkness at $28^{\circ} \mathrm{C}$ for $48 \mathrm{~h}$. The bacteria were then harvested by filtering the contents of each bottle through a $25-\mathrm{mm} \mathrm{GF} / \mathrm{F}$ filter for later analysis. To confirm that no other changes that affected the bacterial signatures in batch cultures, Kritzberg et al. (2004) compared the bacteria isotope signatures in batch tubes with that in situ in dialysis incubation; little difference was found between the two methods. The low and decreasing Chla concentrations, increasing in bacterial abundance and $\mathrm{C}$ : $\mathrm{N}$ ratios of the POM colleted all demonstrated that the measured isotope values of POM in the tubes were attributed to bacteria (Kritzberg et al. 2004)).

Environmental parameters, including temperature, oxidation and reduction potential (ORP), and specific conductivity (SpCond) were monitored on site using a multiparameter meter (model 6600; Yellow Spring Instruments, USA). Total dissolved inorganic nitrogen (DIN) was the sum of ammonium, nitrate and nitrite concentrations. Total nitrogen (TN) was measured by alkaline potassium persulfate digestion-UV spectrophotometric method. Total phosphorus (TP) was digested with potassium persulfate and measured by molybdenum blue colorimetric method.

All samples were freeze-dried to a constant weight and ground to a fine powder using mortar and pestle. For analysis of carbon and nitrogen isotope ratios, all organic samples were combusted in Flash EA1112 elemental analyzer coupled to a Thermo FinniganMAT Deltaplus dual-inlet continuous flow isotope ratio mass spectrometer. The results of isotopic analysis are presented in conventional delta $(\delta)$ notation, defined as $\delta \mathrm{X}=\left[\left(\mathrm{R}_{\text {sample }} / \mathrm{R}_{\text {standard }}\right)-1\right]$ $\times 1000$, where $X$ is ${ }^{13} \mathrm{C}$ or ${ }^{15} \mathrm{~N}$ and $\mathrm{R}$ is the ratio of ${ }^{13} \mathrm{C} /{ }^{12} \mathrm{C}$ or ${ }^{15} \mathrm{~N} /{ }^{14} \mathrm{~N}$. Isotopic ratios are expressed relative to VPDB (Vienna Pee Dee Belemnite) for $\delta^{13} \mathrm{C}$ and to atmospheric nitrogen for $\delta^{15} \mathrm{~N}$. Precision for the analyses was better than $\pm 0.1 \%$ o for both carbon and nitrogen.

\section{Results}

\section{Environmental dynamics}

Water temperature ranged from 4.65 to $29.99^{\circ} \mathrm{C}$ for the different sample dates, with lowest temperature recorded in January, and highest recorded in August (Fig. 1).Total nitrogen concentrations ranged from 1.005 to 1.839 $\mathrm{mgL}^{-1}$ at Estuary, and ranged from 0.105 to $0.986 \mathrm{mgL}^{-1}$
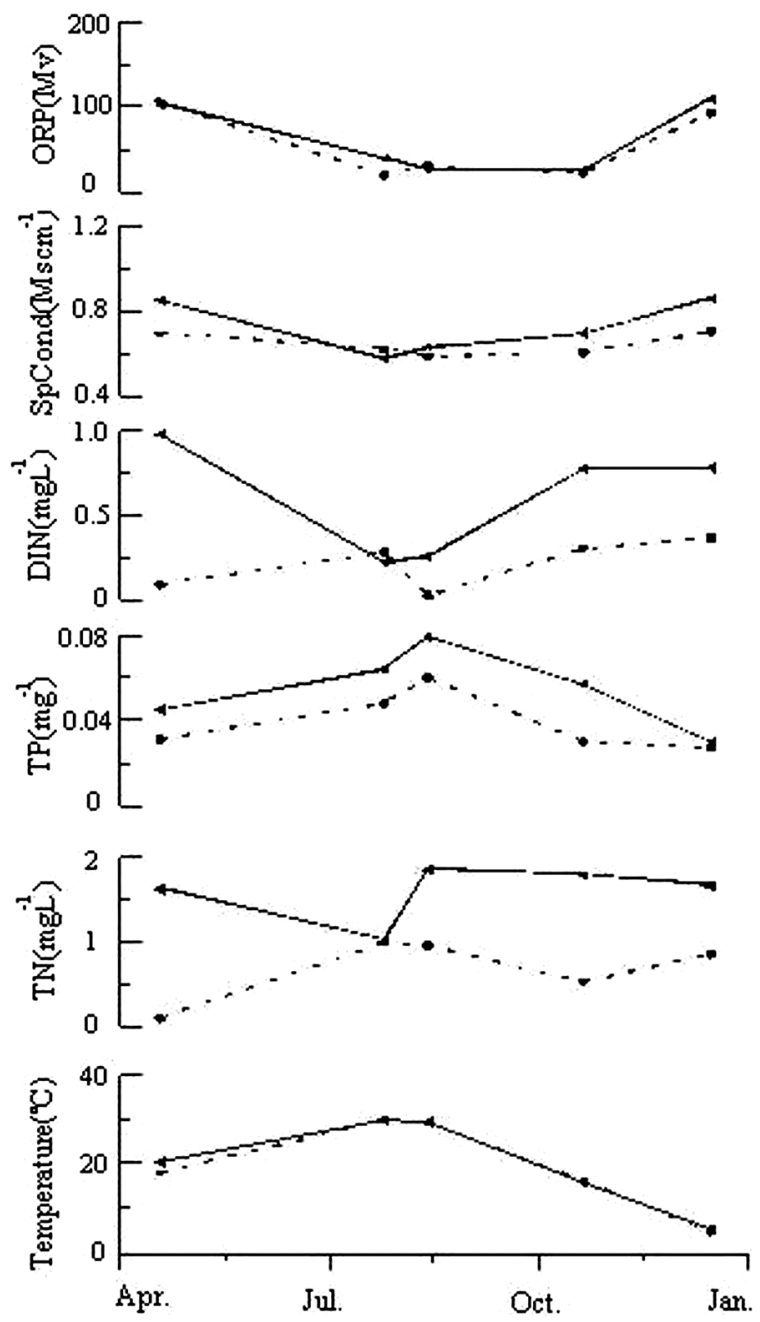

Fig. 1 Seasonal variation in temperature, total nitrogen $(\mathrm{TN})$, total phosphorus (TP), dissolved inorganic nitrogen (DIN), specific conductivity (SpCond), and oxidation and reduction potential (ORP) recorded at Estuary (solid line) and Lake Center (broken line) in Taihu Lake. 
at Lake Center. Total phosphorus concentrations tended to be highest during the more productive times of the year and showed significantly correlation with temperature (Pearson's $r=0.779, p=0.008$ ). Throughout the year, highest concentrations of DIN occurred in winter and lowest concentrations in summer. SpCond exhibited strikingly similar patterns with DIN (Pearson's $r=0.821$, $p=0.004)$. ORP ranged from 20 to $109 \mathrm{Mv}$ at the study sites for the dates sampled with similar seasonal patterns with SpCond (Fig. 1). This was illustrated by the significant positive correlation between ORP and SpCond (Pearson's $r=0.797, p=0.006$ ).

\section{$\delta^{13} \mathrm{C}$ and $\delta^{15} \mathrm{~N}$ signature of food web components}

The bulk $\delta^{13} \mathrm{C}$ composition of POM over the sampling period ranged from $-35.4 \%$ o to $-22.2 \%$ and was generally enriched during summer when both primary production rates and temperatures increased (Fig. 2). Similarly, $\delta^{13} \mathrm{C}$ of cladoceran fraction ranged from $-34.8 \%$ to $-21.0 \%$ and showed a significant correlation with that of POM (Pearson's $r=0.719, p=0.019)$. The bacteria became enriched in $\delta^{13} \mathrm{C}$ compared with that of DOM throughout the sampling dates. ${ }^{13} \mathrm{C}$ values of $\mathrm{POM}$, cladoceran and bacteria were negative significantly correlated with ORP and SpCond (all of the significant coefficients $p<0.05$, data not shown).

The $\delta^{15} \mathrm{~N}$ signature of food web components was different. The cladoceran were usually the most enriched fraction, with annual mean $\delta^{15} \mathrm{~N}$ values of $10.7 \pm 7.2 \%$ o
$( \pm 1$ SD) at Estuary and $12.8 \pm 4.4 \%$ at Lake Center, whereas the other three fractions were more depleted in $\delta^{15} \mathrm{~N}$ (Fig. 2). The POM $\delta^{15} \mathrm{~N}$ signature markedly correlated with its $\delta^{13} \mathrm{C}$ (Pearson's $r=0.719, p=0.017$ ), with the most enriched isotope ratios during the summer months when DIN nutrients were at their lowest concentrations relative to the other sampling periods. To explore if this shift was due to an environmental change, linear regression analyses between POM isotope ratios and DIN concentrations were performed. The results obtained (Pearson's $r=0.871, p=0.001$ for ${ }^{13} \mathrm{C}$; Pearson's $r=0.900, p<0.001$ for $\delta^{15} \mathrm{~N}$ ) revealed that the higher the DIN concentration, the lighter the $\delta^{13} \mathrm{C}$ and $\delta^{15} \mathrm{~N}$ of POM (Fig. 3).

In general, the food web components were slightly more ${ }^{13} \mathrm{C}$ and ${ }^{15} \mathrm{~N}$ depleted at Estuary than that at lake Center during the study period (Fig. 4). But the differences were not significant except for the $\delta^{13} \mathrm{C}$ of bacteria $(t=4.991, \mathrm{df}=4, p=0.008)$.

\section{Discussion}

Stable isotope-based estimates of trophic position provide a powerful fusion of trophic level and food web paradigms for evaluating realized trophic structure of complex food webs. Because it is labor-intensive to isolate sufficient numbers of pure organisms for stable isotope analysis, the bulk cladoceran was selected as primary consumer, which can graze a wide range of
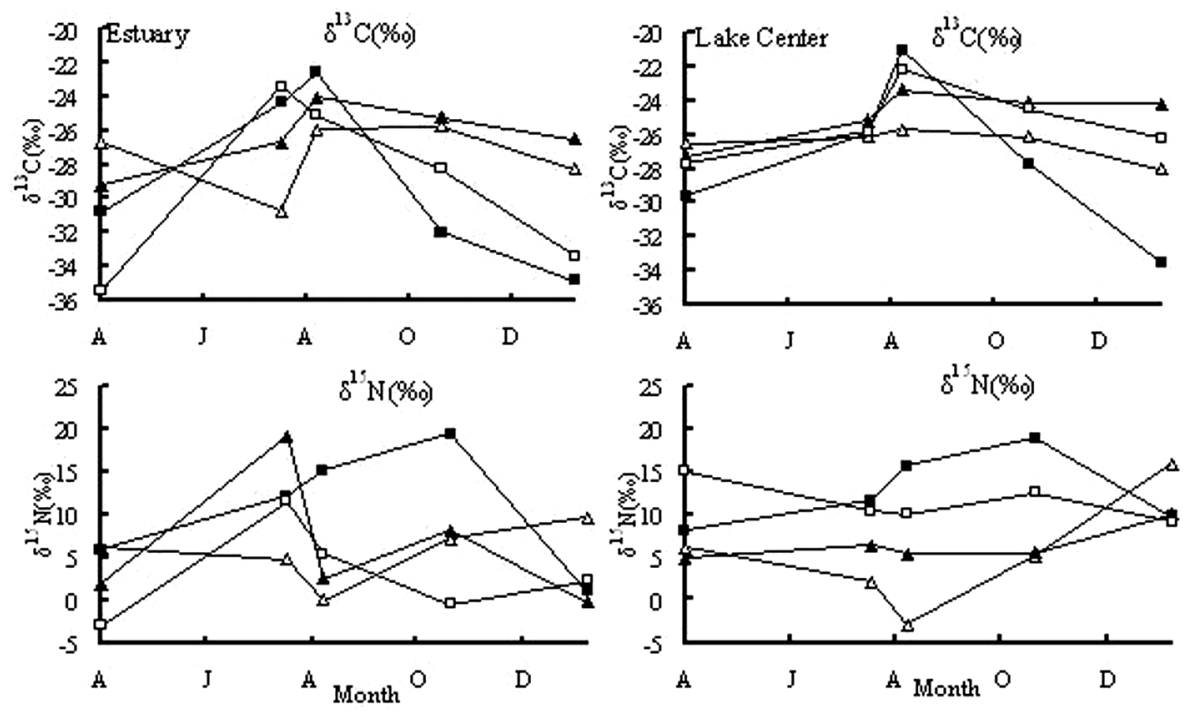

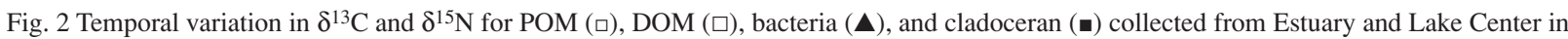
Taihu Lake. 


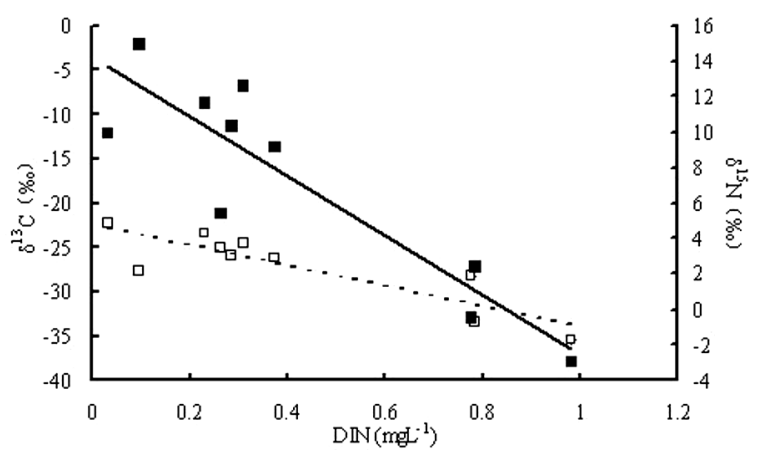

Fig. 3 Relationships between the $\delta^{13} \mathrm{C}(\square)$ and $\delta^{15} \mathrm{~N}(\boldsymbol{m})$ of POM and DIN concentrations in Taihu Lake during the study periods. The solid regression line: $\delta^{15} \mathrm{~N}=16.765$ [DIN] $]+14.231 \quad\left(r^{2}=0.810\right.$, $p<0.001, \mathrm{n}=10)$; the broken regression line: ${ }^{13} \mathrm{C}=11.483$ [DIN] $-22.467\left(r^{2}=0.759, p=0.001, \mathrm{n}=10\right)$.

POM, including phytoplankton, bacteria and detritus. Therefore the bulk, undifferentiated POM, for which we determined the $\delta^{13} \mathrm{C}$ values, can be considered the putative food source for the cladoceran $(r=0.719, p=0.019)$. No significant positive relationship was found between the $\delta^{13} \mathrm{C}$ of bacteria and cladoceran during the sampling dates $(r=0.392, p=0.262)$. Bacteria could reflect the stable isotope composition of the organic matter they grow on it (Coffin et al. 1989, Hullar et al. 1996). The fractionations between bacteria and DOC ranged from $-2.6 \%$ o to $4.0 \%$, a little larger than that have been reported $2 \%$ (Coffin et al. 1989). Selective utilization of autochthonous versus allochthonous $\mathrm{C}$ for microbial growth has been reported in many studies. Generally, bacteria preferentially utilized low molecular weight phytoplankton-derived $\mathrm{C}$ instead of high molecular weight allochthonous C (Kritzberg et al. 2004, McCallister et al. 2006). The $\delta^{13} \mathrm{C}$ values of bacteria changed along with the values of POM during the study, suggesting the assimilation of photochemically enriched $C(r=0.743$, $p=0.014)$.

In the present study, pronounced seasonal changes with a summer maximum in $\delta^{13} \mathrm{C}$ were evident in POM, DOM, cladoceran, and bacteria from both sites of the eutrophic lake (Fig. 2). The characteristic seasonal cycle has been reported in several studies. Rolff (2000) reported a bimodal distribution of $\delta^{13} \mathrm{C}$, with a spring and autumn maximum enrichment for size-fractionated plankton in the Baltic Sea. Xu et al. (2005) found enrichment of $\delta^{13} \mathrm{C}$ in seston and lake anchovy with the progression of the summer bloom. Zohary et al. (1994) found, in a long-term study of plankton in Lake Kinneret (1971 to 1992), that $\delta^{13} \mathrm{C}$ was most depleted during winter in both phyto- and zooplankton. The general seasonal pattern for $\delta^{13} \mathrm{C}_{\mathrm{POM}}$ in Taihu Lake may be related to water temperature, productivity, and dissolved inorganic carbon (DIC) pool size. In early summer, phytoplankton (overwhelmingly dominated by cyanobacteria) photosynthesis in Taihu Lake increased as water temperature increased, resulting in low dissolved nutrients and DIC concentration. A high rate of $\mathrm{CO}_{2}$ uptake results in increases in $\mathrm{pH}$ and a switch in the $\mathrm{C}$ balance from $\mathrm{CO}_{2}$ to $\mathrm{HCO}_{3}{ }^{-}$dominance, which is the major form of DIC $(\mathrm{Gu}$ et al. 2006). Since $\delta^{13} \mathrm{C}$ of $\mathrm{HCO}_{3}{ }^{-}$is on average $8 \%$ o higher than that of dissolved free $\mathrm{CO}_{2}$ (Mook et al. 1974), cyanobacteia are enriched with ${ }^{13} \mathrm{C}$ when using $\mathrm{HCO}_{3}{ }^{-}$ as their $\mathrm{C}$ source. Therefore, $\delta^{13} \mathrm{C}_{\mathrm{POM}}$ increased along with the increases in water temperature, Chla, and decreases in DIN $(r=0.871, p=0.001)$ and DIC concentrations.

The seasonal pattern of the four organic matter fractions $\delta^{15} \mathrm{~N}$ was not uniform compared with that of corresponding $\delta^{13} \mathrm{C}$. The $\delta^{15} \mathrm{~N}_{\mathrm{POM}}$ values markedly correlated with its $\delta^{13} \mathrm{C}(r=0.719, p=0.017)$, with the most enriched isotope ratios during the summer months, though the pattern in lake center was not obvious. Mariotti et al. (1984) and Goering et al. (1990) observed enrichment of $\delta^{15} \mathrm{~N}$ in phytoplankton and seston during summer. They attributed the summertime increase in $\delta^{15} \mathrm{~N}$ to decreased fractionation during rapid phytoplankton growth in warmer months. The magnitude of fractionation depends on species, light, growth rate, and $\mathrm{N}$ concentration (Needoba et al. 2003). The degree of fractionation should be lower with more rapid growth and lower N concentrations (Wada \& Hattori 1978). In summer, higher temperature could have promoted DIN loss via phytoplankton uptake or microbial processes such as nitrification-denitrification. Correspondingly, the phytoplankton becomes progressively enriched in $\delta^{15} \mathrm{~N}$ as DIN is removed from the water (Bode \& Alvarez-Ossorio 2004). The linear increase in $\mathrm{POM} \delta^{15} \mathrm{~N}$ as temperature increases and DIN decreases in our study, fits well with the described above. Alternatively, York et al. (2007) suggested that the extent of fractionation did not vary but the $\delta^{15} \mathrm{~N}$ of the DIN source increased in warmer months and that this increase was reflected in the ${ }^{15} \mathrm{~N}$ of phytoplankton. Unfortunately, since no quantitative measurement of $\delta^{15} \mathrm{NO}_{3}{ }^{-}, \delta^{15} \mathrm{NH}_{4}{ }^{+}$, and the fractionation factor for phytoplankton $\mathrm{N}$ use, we have no evidence for the proper explanation for ${ }^{15} \mathrm{~N}_{\mathrm{POM}}$ seasonality.

The four organic compositions collected at Estuary, with high TN, TP, DIN, SpCond, and ORP, showed slightly lighter $\delta^{13} \mathrm{C}$ and $\delta^{15} \mathrm{~N}$ than that at Lake Center (Fig. 4). This finding was contrary to others, who considered that high levels of anthropogenically derived $\mathrm{N}$ and $\mathrm{C}$ at estuary may introduce a relatively high $\delta^{13} \mathrm{C}$ and 

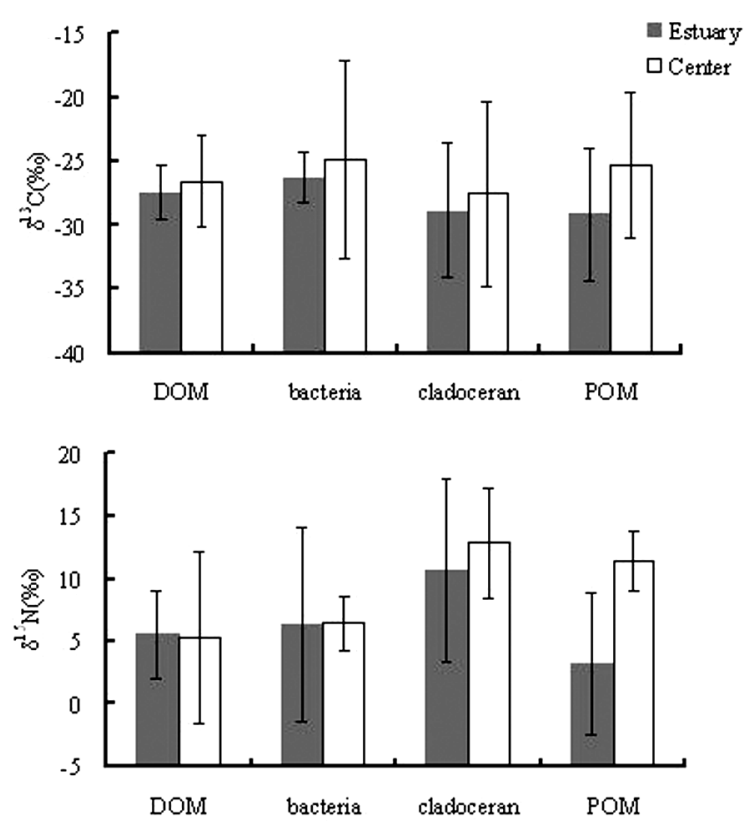

Fig. 4 Spatial variation in $\delta^{13} \mathrm{C}$ and $\delta^{15} \mathrm{~N}$ for POM, DOM, bacteria, and cladoceran from both sample sites (see Fig. 2; means \pm 1 SD). $\delta^{13} \mathrm{C}$ and $\delta^{15} \mathrm{~N}$ values are means of all sampling dates from each site $(\mathrm{n}=5)$.

$\delta^{15} \mathrm{~N}$ values of seston (Vo \& Struck 1997, Kendall et al. 2001, Xu et al. 2005). In contrast, other studies have also shown how the incorporation of low $\delta^{15} \mathrm{~N}$ from point-source inputs of POM derived from domestic waste can result in whole food webs components having lower $\delta^{15} \mathrm{~N}$ in impacted sites than in non-impacted sites (Van Dover et al. 1992, Tucker et al. 1999, DeBruyn \& Rasmussen 2002). One explanation for the depleted $\delta^{13} \mathrm{C}$ may contribute to the effects of microbial activities. Microbial degradation selectively removes labile ${ }^{13} \mathrm{C}$-enriched components such as proteins and carbohydrates, leaving more refractory ${ }^{13} \mathrm{C}$-depleted biochemicals findings such as cellulose, lipid, and lignin that come from the land (Benner et al. 1987, Cloern et al. 2002). So all taxa collected at Estuary reflected substantial sewage influence in their stable isotopic signatures.

\section{Acknowledgements}

We thank X.D. Wu for help with sampling and E.L. Zhang for stable isotope analyses. This work has been supported by State Key Basic Research and Development Plan (No. 2002CB412305), the National Natural Science Foundation of China (No. 40671068) and the One-Hundred-Scientist Program of CAS.

\section{References}

Bastviken D., Ejlertsson J., Sundh I. \& Tranvik L. 2003. — Methane as a source of carbon and energy for lake pelagic food webs. Ecology, 84, 969-981.

Benner R., Fogel M.L., Sprague E.K. \& Hodson R.E. 1987. Depleted of ${ }^{13} \mathrm{C}$ in lignin and its implications for stable carbon isotope studies. Nature, 329, 708-710.

Bode A. \& Alvarez-Ossorio M.T. 2004. - Taxonomic versus trophic structure of mesozooplankton: a seasonal study of species succession and stable carbon and nitrogen isotopes in a coastal upwelling ecosystem. J. Mar. Sci., 61, 563-571.

Cloern J.E., Canuel E.A. \& Harris D. 2002. — Stable carbon and nitrogen isotope composition of aquatic and terrestrial plants of the San Francisco Bay estuarine system. Limnol. Oceanogr., 47, 713-729.

Coffin R.B., Fry B., Peterson B.J. \& Wright R.T. 1989. — Carbon isotope composition of estuarine bacteria. Limnol. Oceanogr., 34, 1305-1310.

DeBruyn A.M.H. \& Rasmussen J.B. 2002. - Quantifying assimilation of sewage-derived organic matter by riverine benthos. Ecol. Appl., 12, 511-520.

Goering J., Alexander V. \& Haubenstock N. 1990. - Seasonal variability of stable carbon and nitrogen isotope ratios of organisms in a North Pacific Bay. Estuarine, Coast. Shelf Sci., 30, 239-260.

Grey J., Jones R.I. \& Sleep D. 2001. - Seasonal changes in the importance of the source of organic matter to the diet of zooplankton in Loch Ness, as indicated by stable isotope analysis. Limnol. Oceanogr., 46, 505-513.

Grey J., Kelly A., Ward S., et al. 2004. - Seasonal changes in the stable isotope values of lake-dwelling chironomid larvae in relation to feeding and life cycle variability. Freshwater Bio., 49, 681-689.

Gu B.H., Chapman A.D. \& Schelske C.L. 2006. - Factors controlling seasonal variations in stable isotope composition of particulate organic matter in a soft water eutrophic lake. Limnol. Oceanogr., 51(6), 2837-2848.

Hu W.P., Jørgensen S.E. \& Zhang F.B. 2006. - A vertical-compressed three-dimensional ecological model in Lake Taihu, China. Ecological Modelling, 190, 367-398.

Hullar M.A.J., Fry B., Peterson B.J. \& Wright R.T. 1996. Microbial utilization of estuarine dissolved organic carbon: a stable isotope tracer approach tested by mass balance. Appl. Environ. Microbio., 62(7), 2489-2493.

Kendall C., Silva S.R. \& Kelly V.J. 2001. — Carbon and nitrogen isotopic compositions of particulate organic matter in four large river systems across the United States. Hydrolo. Process., 15, 1301-1346.

Kong F.X. \& Gao G. 2005. - Hypothesis on cyanobacteria bloom forming mechanism in large shallow lakes. Acta Ecolo. Sinica, 25, 589-595 (in Chinese with English abstract).

Kritzberg E.S., Cole J.J., Pace M.L., et al. 2004. — Autochthonous versus allochthonous carbon sources of bacteria: Results from whole-lake ${ }^{13} \mathrm{C}$ addition experiments. Limnol. Oceanogr., 49(2), 588-596.

Mariotti A., Lancelot C. \& Billen G. 1984. — Natural isotopic composition of nitrogen as a tracer of origin for suspended organic matter in the Scheldt estuary. Geochim. Cosmochim. Acta., 48, 549-555.

McCallister S.L., Bauer J.E. \& Canuel E.A. 2006. - Bioreactivity of estuarine dissolved organic matter: A combined geochemical and microbiological approach. Limnol.Oceanogr., 51(1), 94-100. 
Mook W.G., Bommerson J.C. \& Stavermen W.H. 1974. — Carbon isotope fractionation between dissolved bicarbonate and gaseous carbon dioxide. Earth Planet. Sci. Lett., 23, 169-176.

Needoba J.A., Waser N.A., Harrison P.J. \& Calvert S.E. 2003. Nitrogen isotope fractionation in 12 species of marine phytoplankton during growth on nitrate. Mar. Ecol. Prog. Ser., 255, 81-91.

Rolff C. 2000. - Seasonal variation in ${ }^{13} \mathrm{C}$ and ${ }^{15} \mathrm{~N}$ of size-fractionated plankton at a coastal station in the northern Baltic proper. Mar. Ecol. Prog. Ser., 203, 47-65.

Tucker J., Sheats N., Giblin A.E., Hopkinson C.S. \& Montoya J.P. 1999. - Using stable isotopes to trace sewage-derived material through Boston Harbor and Massachusetts Bay. Mar. Environ. Res., 48, 353-375.

Van Dover C.L., Grassle J.F., Fry B., Garritt R.H. \& Starczak V.R. 1992. - Stable isotope evidence for entry of sewage-derived organic material into a deep-sea food web. Nature, 360, 153-155.
Vo M. \& Struck U. 1997. - Stable nitrogen and carbon isotopes as indicator of eutrophication of the Oder river (Balticsea). Marine Chemistry, 59, 35-49.

Wada E. \& Hattori A. 1978. - Nitrogen isotope effects in the assimilation of inorganic nitrogenous compounds by marine diatoms. Geomicrobiology, 1, 85-101.

Xu J., Xie P., Zhang M. \& Yang H. 2005. - Variation in stable isotope signatures of seston and a zooplanktivorous fish in a eutrophic Chinese lake. Hydrobiologia, 2005, 541, 215-220.

York J.K., Tomasky G., Valiela I. \& Repeta D.J. 2007. — Stable isotopic detection of ammonium and nitrate assimilation by phytoplankton in the Waquait Bay estuarine system. Limnol. Oceanogr., 52, 144-155.

Zohary T., Erez J., Gophen M., Berman-Frank I. \& Stiller M. 1994. - Seasonality of stable carbon isotopes within the pelagic food web of Lake Kinneret. Limnol. Oceanogr., 39, 1030-1043. 